\title{
Assessing Ehealth Technology
}

\author{
Hans C. Ossebaard* \\ National Health Care Institute, The Netherlands
}

Submission: July 30, 2017; Published: August 10, 2017

*Corresponding author: Dr. Hans C. Ossebaard, National Health Care Institute / University of Twente, P.O. Box 320, 1110 AH Diemen, The Netherlands. Tel: +31 (0)20 79784 10; Fax: +31 (0)20 79785 00; Email: hossebaard@zinl.nl

\begin{abstract}
Several reasons explain why widespread application of information and communication technology in health care is limited in the Netherlands. One of these is the complexity of assessing the quality of eHealth technologies We conducted a field consultation to clarify the issue. Different stakeholders (patients, innovators, payers, insurers, providers, researchers) need different kinds of proof to substantiate their decisions. Scientific evidence is not always appropriate or even necessary. Assessment methods differ according to the needs and values of the respective stakeholders and the local policy contexts within which they operate. New methods are developed to address the dynamic, social nature of eHealth interventions. A systematic approach that comprises posing the right questions, cooperating strategically and using multiple sources can reduce uncertainty, facilitate decision-making and support innovation in health.
\end{abstract}

Keywords: Telemedicine; Quality of health care; Diffusion of innovation; Medical informatics; Technology assessment; Biomedical

\section{Introduction}

Contrary to perception, the application of information and communication technology in Dutch health care is rather limited. Nonetheless the necessary conditions for widespread use of eHealth are clearly present: broadband access and availability of the internet, a tech savvy, relatively well-educated population, relative economic prosperity, a creative digital industry, a stimulating eHealth policy, national urgencies, pressing international developments et cetera. Even so, eHealth application in health care is fragmented and at only implemented at a small scale. The eHealth Monitor [1] maps out the status of eHealth in The Netherlands on a yearly basis. It identified four clusters of issues that cause this low level of adoption: a commonly deficient standardization of data exchange, poor knowledge among both health professionals and patients, financial issues and lack of vision and leadership. And of course, though not always too obvious: innovation is not identical with improvement. Many innovations do not serve appropriate care, i.e. a better patient journey against lower costs, preferably reducing the over use of ineffective care [2]. On the contrary they may lead to medicalisation, loss of autonomy, less health and higher costs. Admittedly, the evidence base of eHealth solutions is growing but is still relatively modest when it comes to effectiveness and efficacy across patient populations or throughout the health care system and beyond. This further impedes the assessment of eHealth technologies from within different policy contexts and different stakeholder perspectives.

Such issues are familiar to many other countries that seek to transform their health care systems to meet changing conditions [3]. To overcome such barriers it is necessary to address them in-depth and to focus on what works in order to implement effective eHealth solutions [4]. But precisely the latter is hard to establish. How to assess the potential benefits- and risks - of eHealth technologies? Decision-makers in different contexts would answer this question differently according to their specific perspectives. A hospital CEO, an innovator, an insurer, a patient federation's representative, a regulator, a health care provider, a researcher -they all would appreciate the alleged benefits according to their own respective value systems. They wrestle with uncertainties that cannot easily be solved, they may postpone or even cancel investment decisions and at the end of the day all parties concerned regret the slow pace of innovation.

A common value among different stakeholders would be quality. However hard to define, IOM's quality dimensions are widely recognized [5]. Decision-maker's use these to prioritize improvement measures, but the dimensions themselves are value-laden. They may reinforce, impair or complement each other. E.g., emphasizing patient safety may result in less trust. The overriding considerations will be based on the value 
hierarchy of the stakeholders involved. 'Value' is often used to connect diverging perspectives. Porter \& Teisberg [6] view patient value as the central, overarching goal of health care and as an instrument to improve it. Discussions about eHealth often advance effectiveness, safety and privacy [7] while the public values are basically accessibility, affordability and quality of care. Sometimes diverging values can be reconciled, sometimes they differ too much.

The evidence-base for eHealth is now gradually improving and the contribution of eHealth to cost-effectiveness and quality is unmistakably present [8]. It may differ per technology, per sector, per process of care and per end-user but it is there. Though this is of great importance we still must acknowledge that "decisions on health IT development and implementation are based on 'what we think makes sense, what we can afford, what vendors recommend...' [...] - and not on scientific evidence" [9].

In an effort to reduce uncertainty in decision-making, facilitate assessing the 'value' of these technologies, thereby accelerating appropriate innovation, we have undertaken a focussed field consultation among stakeholders in health care (patients, innovators, payers, insurers, providers, researchers). All participants recognized the issue as an important obstacle for adoption. eHealth is a container concept that only gains precision when the end-user, the care context and the technology in question are designated. As a young, transdisciplinary notion it refers to complex social situations where digital technologies enable innovative medical products, new forms of care delivery, organization and behaviour. The Health Technology Assessment (HTA) community is in the process of developing new methods such as early dialogue and the use of real world data to meet contemporary challenges in medicine research [10]. The eHealth research community is searching for appropriate methodologies 'beyond' randomized clinical trials in the context of a what seems to be a diminishing trust in evidence-based medicine [11]. HTA and eHealth may be a productive combination to explore [12]. At the end of the day the context seems to define value prioritization in the assessment of the relative power of evidence. For researchers the value of 'scientific evidence' is quite different compared to an executive board of a hospital.

Involving stakeholders in the process of clarifying value in eHealth technology assessment has eventually led to the cocreation, and publication, of a discussion paper [13]. It provides no simple answers but delineates what is needed to reduce uncertainty in decision-making. Depending on the maturity of an eHealth intervention, stakeholders need to pose the right questions as a first step to assess quality. A systematic approach helps to improve the odds for successful implementation. Here it is vital to develop productive cooperation to serve private and public interests. Using several sources is critical to evaluate quality in context. A tailored, situated approach is required since quality and price differ per sector, per context, technology, maturity stage, user group. To better compare sources eHealth research needs to become more standardized thus enabling to balance the outcomes and contribute to meaningful knowledge accumulation. Which is necessary after eHealth being on the verge of break-through for over fifteen years.

\section{Conclusion}

There is no one-size-fits-all approach to assess the merits of eHealth technology. The choice of methods to assess benefits and risk varies according to the policy context and the values of the decision-maker Organizing early dialogue, interactive governance and forms of collective learning offer new opportunities for cyclic development, introduction, adoption and evaluation of digital technologies in health care. Engaging stakeholders in the process is indispensable.

\section{Acknowledgement}

a) We wish to thank all stakeholders for their time and contribution to the field consultation. We also thank Nictiz, the Dutch national competence centre for standardisation and eHealth, for collaborating in this area.

b) This paper does not necessarily reflect the position of the Dutch National Health Care Institute.

c) This project received no specific grant from any funding agency, commercial or not-for-profit sectors.

\section{References}

1. eHealth Monitor 2016. https://www.nictiz.nl/SiteCollectionDocuments/ Rapporten/ENG_summary_eHealth-monitor_2016.pdf

2. Berwick DM (2017) Avoiding overuse - the next quality frontier. Lancet 390(10090): 102-104.

3. Dorsey ER, Topol EJ (2016) State of Telehealth N Engl J Med 375(2): 154-161.

4. Ossebaard HC, Van Gemert-Pijnen JEWC (2016) eHealth and quality in health care: Implementation time. Int J Quality in Health Care 28(3): 415-419.

5. Institute of Medicine (2001), Committee on the Quality of Health Care in America. Crossing the quality chasm: A new health system for the 21st century. Washington, DC: National Academy Press.

6. Porter ME, Teisberg EO (2006) Redefining health care: Creating valuebased competition on results. Boston: Harvard Business School Press, USA.

7. Krupinski EA, Bernard J (2014) Standards and guidelines in telemedicine and telehealth. Healthcare 2(1): 74-93.

8. Totten AM, Womack DM, Eden KB, McDonagh MS, Griffin JC, Grusing S, Hersh WR. Telehealth: Mapping the Evidence for Patient Outcomes From Systematic Reviews. Technical Brief No. 26. (Prepared by the Pacific Northwest Evidence-based Practice Center under Contract No. 290-2015-00009-I.) AHRQ Publication No.16-EHC034-EF. Rockville, MD: Agency for Healthcare Research and Quality; June 2016. www. effectivehealthcare.ahrq.gov/reports/final.cfm.

9. Ammenwerth E (2015) Evidence-based Health Informatics: How Do We Know What We Know? Methods Inf Med 54(4): 298-307.

10. Makady A, Ham RT, de Boer A, Hillege H, Klungel O, et al. (2017) Policies for use of real-world data in health technology assessment (HTA): a comparative study of six HTA agencies. Value Health 20(4): 520-532. 
11. Greenhalgh T, Howick J, Maskrey N (2014) Evidence based medicine: a movement in crisis? British Medical Journal 348: g3725.

12. Oortwijn W, Van der Wilt GJ (2016) Challenges in contemporary health technology assessment: a view from the outside. Int J of Technology Assessment in Health Care 32(1-2): 1-2.
13. Ossebaard HC, Van Duivenboden J, Krijgsman J (2017) Evaluatie van eHealth-technologie in de context van beleid. Discussie-paper [ Evaluation of eHealth technology in the context of policy. Discussion paper 2017]. ISBN 978-90-820304-8-8. Den Haag/Diemen: Nictiz/ Zorginstituut Nederland.

Your next submission with Juniper Publishers will reach you the below assets

- Quality Editorial service

- Swift Peer Review

- Reprints availability

- E-prints Service

- Manuscript Podcast for convenient understanding

- Global attainment for your research

- Manuscript accessibility in different formats ( Pdf, E-pub, Full Text, Audio)

- Unceasing customer service

Track the below URL for one-step submission https://juniperpublishers.com/online-submission.php 